\title{
PEMBELAJARAN INTEGRATIF DALAM MATAKULIAH MATERI DAN PEMBELAJARAN IPA SD DENGAN KONSEP DASAR IPA PADA MAHASISWA S1 PGSD UT SURABAYA
}

\author{
Wuwuh Asrining Surasmi (wuwuh@ut.ac.id) \\ Jurusan PGSD, FKIP, UPBJJ-UT Surabaya \\ Supardiyono \\ Jurusan Fisika FMIPA UNESA Kampus Ketintang Surabaya
}

\begin{abstract}
ABSTRAK
Untuk meningkatkan kualitas pendidikan IPA di SD langkah pertama yang dilakukan adalah meningkatkan kualitas guru dan calon guru IPA di SD, khususnya di lembaga pendidikan guru, salah satunya adalah di UT. Penelitian ini bertujuan untuk pertama mendeskripsikan model implementasi pembelajaran integratif dalam kegiatan tutorial matakuliah Materi dan Pembelajaran IPA SD dengan Konsep Dasar IPA pada mahasiswa S-1 PGSD pokjar Kabupaten Tuban. Kedua untuk mendeskripsikan efektifitas implementasi pembelajaran integratif dalam kegiatan tutorial matakuliah Materi dan Pembelajaran IPA SD dengan Konsep Dasar IPA dalam meningkatkan penguasaan konsep dasar IPA dan kemampuan membuat perencanaan pembelajaran pada mahasiswa S-1 PGSD pokjar Kabupaten Tuban. Ketiga untuk mendeskripsikan besar pengaruh implementasi pembelajaran integratif dalam kegiatan tutorial matakuliah Materi dan Pembelajaran IPA SD dengan Konsep Dasar IPA terhadap prestasi belajar matakuliah Materi dan Pembelajaran IPA SD pada mahasiswa S-1 PGSD Pokjar Kabupaten Tuban. Penelitian ini merupakan penelitian pengembangan perangkat pembelajaran yang berupa: Rancangan Aktivitas Tutorial (RAT), Satuan Acara Tutorial (SAT), Rancangan Evaluasi (RE), dan Lembar Kerja Mahasiswa (LKM). Pengembangan perangkat mengacu pada four D model yang dikemukakan oleh Thiagarajan dan Semmel (1974:6). Perangkat pembelajaran yang dikembangkan cukup layak digunakan, dapat meningkatkan kemampuan membuat RPP dan hasil belajar mahasiswa.
\end{abstract}

Kata kunci: IPA, pembelajaran integratif, 4D model

\begin{abstract}
To improve the quality of science education in elementary first step is to improve the quality of teachers and prospective science teachers in primary schools, especially in teacher education institutions, one of which is in UT. This study aims to describe the first implementation model of integrative learning in the course material and tutorial activities Elementary Science Lesson with IPA Basic Concepts in the S-1 student PGSD pokjar Tuban. Secondly to describe the effectiveness of the implementation of integrative learning in the course material and tutorial activities Elementary Science Lesson with IPA Basic Concepts in improving the mastery of basic science concepts and the ability to plan student learning in the S-1 PGSD pokjar Tuban. Third to describe the influence of the implementation of integrative learning in the course material and tutorial activities Elementary Science Lesson with IPA Basic Concepts on learning achievement and course materials to students of elementary Science Lesson S-1 PGSD Pokjar Tuban.
\end{abstract}


This research is the development of learning tools such as: Design Activity Tutorial (RAT), Unit Events Tutorial (SAT), Draft Evaluation (RE), and the Student Worksheet (MFI).

Software development refers to the four D model proposed by Thiagarajan and Semmel

(1974:6). Learning tools developed quite fit for use, can improve the ability to make lesson plans and student learning outcomes.

Keywords: integrative learning, science, 4D models

Isu tentang rendahnya kualitas hasil belajar mata pelajaran ilmu pengetahuan alam (IPA) di Sekolah Dasar (SD) hingga saat ini masih sering terdengar di masyarakat. Salah satu indikator yang dijadikan acuan adalah rendahnya nilai NEM IPA siswa lulusan SD dibandingkan dengan bidang studi lainnya (Sumaji, 1998:8). Di samping itu di lapangan (sekolah) ditemukan banyak siswa sekolah dasar (SD) yang kurang memahami konsep IPA. Salah satu pihak yang banyak disoroti dalam peningkatan mutu pendidikan dan hasil belajar IPA adalah guru. Hal ini merupakan suatu kewajaran mengingat guru memegang peranan penting dalam proses pendidikan dan pengajaran di sekolah. Bahkan dinyatakan bahwa guru memberikan kontribusi terbesar (sebesar34\%) terhadap prestasi belajar siswa di sekolah (Sumaji, 1998:9). Peran guru dirasakan semakin penting di tengah-tengah keterbatasan sarana dan prasarana belajar sebagaimana dialami negara-negara berkembang, termasuk Indonesia. Pemahaman konsep IPA yang rendah ini turut disebabkan karena segi-segi ideal pengajaran sains banyak ditinggalkan guru (Sumaji, 1998:9). Cara guru mengajarkan konsep IPA yang sulitdipahami siswa turut berkontribusi terhadap rendahnya pemahaman konsep IPA siswa. Disamping itu isi kurikulum sangat padat dan guru dituntut harus menyelesaikan semua materi dalam waktu yang telah ditentukan. Faktor lainnya adalah guru SD sebagian besar merupakan guru kelas yang harus mengajarkan semua mata pelajaran, kecuali pendidikan Agama dan Penjaskes (Pelajaran pendidikan jasmani dan kesehatan).

Berbagai kebijakan dan reformasi pendidikan untuk peningkatan mutu akan kurang mencapai sasarannya jika tidak menyentuh pihak guru. Kualitas out-put lulusan sangat ditentukan oleh kualitas dan dinamika proses belajar mengajar di kelas yang sangat ditentukan kompetensi profesional guru (Satori, 1996: 15).

Beberapa hasil temuan penelitian tentang kompetensiprofesional guru IPA yang disampaikan pada Rapat Kerja Nasional Depdiknas 1997 adalah; (1) penguasaan dan pemahaman guru terhadap materi pelajaran IPA termasuk rendah, (2) pengetahuan guru tentang metode mengajar belum memadai, (3) Guru belum mampu menggunakan alat-alat IPA (Wahab, 1998:35). Faktor-faktor penyebab yang dikemukakan menyangkut, misalnya, rendahnya mutu pendidikan pra jabatan guru , penataran guru IPA yang belum merata diikuti, kurangnya petunjuk dan dorongan dari kepala sekolah dan pengawas bidang studi, belum dimanfaatkannya buku guru dengan baik.

Membicarakan guru berarti akan melibatkan lembaga "pencetak" guru. Untuk guru SD dipersiapkan dalam jurusan Pendidikan Guru Sekolah Dasar (PGSD). Dalam kurikulurn PGSD UT, perbekalan untuk dapat mengajarkan IPA di SD dengan baik disajikan dalam 2 mata kuliah yang terpisah yaitu Konsep Dasar IPA pada semester satu (1) dan matakuliah Materi dan Pembelajaran IPA di Sekolah Dasar pada semester Sembilan (9) yang masing-masing mempunyai bobot 4 sks. Materi matakuliah Konsep Dasar IPA tidak disinggung sama sekali tentang bagaimana cara mengajarkan materi tersebut di SD, serta metode dan keterampilan proses apa yang digunakan guru agar siswa mudah memahaminya. Akibatnya, mahasiswa PGSD sulit untuk menggabungkan kedua 
mata kuliah itu yang digunakan untuk mengajarkan konsep IPA di SD (Hinduan, 2000:12). Kesulitan ini tentu akan semakin dirasakan oleh mahasiswa PGSD, yang memang berasal dari berbagai lulusan sekolah lanjutan tingkat atas (SLTA), misalnya SMA-IPS, SMK-Ekonomi, SMK-Teknologi, SPG dan SGO.

Kenyataan ini mengisyaratkan perlunya suatu solusi. Salah satunya adalah dengan mengembangkan model tutorial di PGSD UT yang dapat menjembatani matakuliah Konsep Dasar IPA dan matakuliah Materi dan Pembelajaran IPA SD dan dapat mengakomodasi spektrum input mahasiswa yang bermacam-macam. Hal ini menjadi sangat penting mengingat mahasiswa PGSD UT harus mengalami langsung apa yang dipelajarinya dan harus menguasai bahan ajar, mengetahui bagaimana merencanakan, dan mengajarkannya.

Keberadaan Dosen/Tutor PGSD UT yang mampu memberikan "model" bagi mahasiswanya sungguh merupakan faktor yang menentukan bagi persiapan guru IPA SD yang berkualitas.

Tujuan yang ingin dicapai dalam penelitian ini adalah:(1) Mendeskripsikan model implementasi pembelajaran integratif dalam kegiatan tutorial matakuliah Materi dan Pembelajaran IPA SD dengan Konsep Dasar IPA pada mahasiswa S-1 PGSD pokjar Kabupaten Tuban, (2) Mendeskripsikan efektifitas implementasi pembelajaran integratif dalam kegiatan tutorial matakuliah Materi dan Pembelajaran IPA SD dengan Konsep Dasar IPA dalam meningkatkan penguasaan konsep dasar IPA dan kemampuan membuat perencanaan pembelajaran pada mahasiswa S-1 PGSD pokjar Kabupaten Tuban, (3) Mendeskripsikan besar pengaruh implementasi pembelajaran integratif dalam kegiatan tutorial matakuliah Materi dan Pembelajaran IPA SD dengan Konsep Dasar IPA terhadap prestasi belajar matakuliah Materi dan Pembelajaran IPA SD pada mahasiswa S-1 PGSD Pokjar Kabupaten Tuban.

\section{Kajian Teori Kompetensi Dasar Guru IPA SD}

Menurut Schulman (Gabel, 1993:34), seorang guru IPA seharusnya memiliki beberapa kompetensi dasar yang meliputi; (1) kemampuan intelektual umum (general intellectual ability), (2) pengetahuan atau latar belakang materi ajar (subject-matter background), (3) kompetensi pedagogi mengajarkan bidang materi IPA(pedagogical subject-matter competence), (4) Keterampilan dan pengetahuan profesional (professional knowledge and professional skills).

Kemampuan intelektual umum adalah kemampuan-kemampuan yang dimiliki oleh setiap orang, misalnya kemampuan memecahkan masalah, IQ, kemampuan belajar, dan kemampuan yang terkait secara kultural atau kecerdasan intelektual dengan kepribadian. Hasil studi meta-analisis 65 penelitian yang dilakukan Duva \& Anderson (Gabel, 1993:20) menyimpulkan ada korelasi yang rendah (dibawah 0,50) antara karakteristik guru ( dilihat dari; gender, IQ, variabel kepribadian) dengan student outcomes (dilihat dari tes hasil belajar, dan sikap). Akan tetapi diyakini para ahli bahwa kemampuan intelektual guru yang tinggi akan mempengaruhi pemahaman dan penguasaannya tentang pengetahuan materi ajar IPA.

Walaupun hubungan atau korelasi antara kemampuan intelektual umum dengan keterampilan mengajar belum terdokumentasi dengan jelas (Roth \& Pipho, dalam Gabel, 1993:21), namun upaya untuk memilih calon guru di Lembaga Pendidikan Tenaga Kependidikan (LPTK) diarahkan kepada calon yang memiliki kemampuan intelektual yang memenuhi standar tertentu. Misalnya dengan menetapkan nilai tes IQ nya lebih dari 100 atau lebih rendah sedikit dari itu. Di Indonesia tes kemampuan Intelektual (IQ) belum dilakukan sebagai salah satu indikator penerimaan mahasiswa calon guru. 
Kemampuan guru menguasai materi ajar yang akan diajarkannya merupakan suatu keharusan. Untuk memenuhi standar kemampuan profesional semua guru IPA harus mempunyai dasar pengetahuan ilmiah yang kuat dan luas tentang disiplin ilmu yang ditekuninya. Kompetensi guru IPA SD ditinjau dari penguasaan materi ajar tidak hanya terbatas disiplin ilmunya saja, tetapi pengetahuan IPA secara integral (Fisika, Kimia, Biologi, Bumi dan Antariksa), serta Sains Teknologi dan Masyarakat.

\section{Tujuan Pembelajaran IPA di SD}

Tujuan proses belajar mengajar IPA di SD dapat digolongkan pada 6 (enam) kategori, yaitu agar peserta didik, (1) menguasai pengetahuan IPA (knowledge), (2) menguasai keterampilan menggunakan peralatan praktikum IPA (instrumental skills), (3) mempunyai sikap ilmlah kemampuan dan keterampilan pemecahan masalah (problem-solving skills), (4) mempunyai sikap ilmiah (scientific attitudes), (5) mempunyai appresiasi terhadap IPA (appreciations), dan (6) mempunyai minat belajar IPA atau menjadikan IPAsebagai karir (interrests) (Carin \& Sund, 1980:18).

Jika siswa yang belajar IPA di sekolah diduga telah mempunyai berbagai konsepsi tentang konsep atau fenomena alam, maka mengajar IPA juga diarahkan untuk mengubah konsepsi siswa yang mungkin tidak sesuai dengan konsepsi ilmiah (teaching learning science as conceptual change). Konsep-konsep IPA yang dipelajari haruslah mudah dipahami dan dijangkau, masuk akal, dan dirasakan berguna bagi siswa (Bell, 1993: 24). Hal ini tentu menuntut kreativitas dan kapabilitas guru dalam mengelola PBM IPA di sekolah. Pemahaman tentang konten IPA di SD dapat diperolehsiswa melalui kegiatan belajar, baik yang terjadi selama di sekolah (kelas) dan selama di rumah (melalui tugas-tugas $\mathrm{PR}$ ).

\section{Perencaan Program Pembelajaran}

Perencanaan/Pengembangan program pembelajaran adalah rumusan-rumusan tentang apa yang akan dilakukan guru dan peserta didik dalam proses pembelajaran untuk mencapai tujuan, sebelum kegiatan belajar mengajar yang sesungguhnya dilaksanakan. Pengembangan program ini merupakan suatu sistem, yang menjelaskan adanya analisis atau semua komponen pengajaran yang benar-benar harus saling terkait secara fungsional untuk pencapaian tujuan (Ali, 1990:11). Komponen-komponen program pengajaran yang dimaksudkan, meliputi: (a) Perumusan tujuan instruksional yang hendak dicapai itu sendiri; (b) Penetapan bahan ajar yang akan dipelajari; (c) Perumusan kegiatan belajar mengajar yang akan ditempuh; (d) Penetapan metode dan media/alatalat yang sesuai; (e) Penetapan cara penilaian yang akan dilakukan, dan; (f) Penetapan waktu yang dialokasikan untuk pelaksanaan program pembelajaran tersebut.

Sebelum seorang guru menetapkan suatu program pengajaran, ia harus mempelajari dan menguasai GBPP (Garis-Garis Besar Program Pengajaran) terlebih dahulu untuk suatu atau berbagai bidang studi dalam kurikulum yang berlaku pada kelas yang menjadi tanggung jawabnya. Selanjutnya, guru tersebut harus menetapkan sejumlah satuan bahasan (pokok bahasan) yang dimuat dalam GBPP itu ke dalam satuan-satuan pelajaran yang merupakan salah satu bentuk sistem penyampaian.

Langkah-langkah yang harus ditempuh di dalam mengembangkan program pengajaran, meliputi: (1) Merumuskan tujuan pembelajaran khusus (2) Mengembangkan alat evaluasi; (3) Menetapkan kegiatan belajar mengajar; (4) Merencanakan program pengajaran/kegiatan, dan (5) Melaksanakan program dan evaluasi. 
Sistem penyampaian pengajaran dimaksudkan adalah cara-cara yang dapat ditempuh dalam penyajian suatu bahan pelajaran agardapat dipelajari peserta didik dan tujuan pengajaran dapat dicapai. Terdapat berbagai bentuk sistem penyampaian pengajaran yang dapat dilakukan guru, misalnya melalui bentuk renpel, modul, pengajaran berprograma, radio dan televisi pendidikan, model pengajaran unit, dan model pembelajaran terpadu. Pada bagian ini hanya akan dibahas bentuk rencana pembelajaran yang merupakan bentuk yang sering digunakan guru di sekolahsekolah dasar saat ini. Renpel ini merupakan pedoman guru dalam melaksanakan kegiatan belajar mengajar yang mencakup tujuan pembelajaran,materi/bahan pelajaran, uraian, kegiatan belajar mengajar, media/alat dan sumber yang akan dipakai, dan alat evaluasi yang akan digunakan.

\section{Metode Penelitian}

Penelitian ini dikategorikan dalam penelitian pengembangan perangkat pembelajaran yang berupa: Rancangan Aktivitas Tutorial (RAT), Satuan Acara Tutorial (SAT), Rancangan Evaluasi (RE), dan Lembar Kerja Mahasiswa (LKM). Pengembangan perangkat mengacu pada four $D$ model yang dikemukakan oleh Thiagarajan dan Semmel (1974: 6).

Setelah perangkat pembelajaran dikembangkan, dilaksanakan penelitian eksperimen semu untuk 1) melihat keefektifan pembelajaran dengan menggunakan perangkat pembelajaran yang telah dikembangkan tersebut, 2) melihat hasil belajar mahasiswa yang dikenai pembelajaran dengan menggunakan perangkat tersebut.

Penelitian ini terdiri dari tiga tahapan, yaitu: tahap persiapan, tahap pelaksanaan, dan tahap analisis data. Model pengembangan yang akan digunakan untuk mengembangkan perangkat pembelajaran dalam penelitian ini adalah model Thiagarajan, Semmel, dan Semmel (1974:6) yang dikenal dengan Four-D Models (Model 4D). Model 4D dipilih karena sistematis dan cocok untuk mengembangkan perangkat pembelajaran, namun dalam penelitian ini peneliti melakukan modifikasi terhadap model 4D. Hal ini dilakukan karena model 4D ini dirancang untuk pembelajaran bagi siswa luar biasa (exceptional pupils) sedangkan subjek penelitian ini adalah mahasiswa biasa/normal. Modifikasi yang dilakukan adalah berkaitan dengan penyederhanaan model, yaitu pendefinisian (define), perancangan (design), pengembangan (develop), dan desiminasi (desseminate) terbatas. Hal ini dilakukan karena keterbatasan waktu dan kemampuan dari peneliti. Istilah analisis konsep diganti menjadi analisis materi. Hal ini dilakukan karena yang akan dikembangkan adalah perangkat pembelajaran dengan mengintegrasikan materi matakuliah Konsep Dasar IPA dengan materi matakuliah Materi dan Pembelajaran IPA SD. Materi memiliki cakupan yang lebih luas dari pada konsep. Dalam satu materi dapat terdiri dari beberapa konsep. Berikut penjelasan tahap-tahap pengembangan perangkat pembelajaran.

\section{1) Tahap Pendefinisian (Define)}

Pada tahap pendefinisian dilakukan studi pendahuluan mengenai kurikulum pada program studi S1 PGSD, analisis mahasiswa, analisis kompetensi yang akan dicapai dalam matakuliah Materi dan Pembelajaran IPA SD, analisis konsep (struktur isi matakuliah), dan analisis tugas tutorial, kemudian dilakukan pendefinisian pembelajaran integratif antara matakuliah Materi dan Pembelajaran IPA SD dengan Konsep Dasar IPA.

\section{2) Tahap Perancangan (Design)}

Pada tahap perancangan ini dilakukan identifikasi terhadap komponen-komponen matakuliah, meliputi kompetensi yang akan dicapai, pokok dan sub pokok bahasan, aktivitas, media, dan sumber belajar untuk mendukung pencapaian kompetensi, serta evaluasi untuk mengukur pencapaian kompetensi. Komponen-komponen tersebut selanjutnya disusun dalam kerangka dan 
sitematika sesuai dengan format yang berlaku, berupa Rancangan Aktivitas Tutorial (RAT), Satuan Acara Tutorial (SAT), Rancangan Evaluasi (RE), dan Lembar kerja Mahasiswa (LKM).

\section{3) Tahap Pengembangan (Develop)}

Pada tahap pengembangan, semua komponen yang telah siap pada tahap perancangan, meliputi RAT, SAT, RE, dan LKM selanjutnya dijadikan dasar untuk mengembangkan draf I panduan pembelajaran integratif dalam matakuliah Materi dan Pembelajaran IPA SD dengan Konsep Dasar IPA. Tahap ini dilakukan langkah-langkah sebagai berikut: (1) Penyusunan draf 1 Pembelajaran Integratif, (2) Telaah oleh para pakar pembelajaran IPA, (3) Revisi I oleh peneliti, penyusunan draf 2, (4) Tahap Pelaksanaan/ujicoba, (5) Revisi II oleh peneliti, (6) Penyusunan draf 3 (produk akhir penelitian).

Perangkat rencana tutorial matakuliah Materi dan Pembelajaran IPA SD yang telah disusun, mencakup: RAT, SAT, RE, dan LKM berupa draf 1 pembelajaran Integratif ditelaah oleh pakar pembelajaran IPA. Berdasarkan hasil telaah tersebut kemudian perangkat rencana tutorial direvisi (revisi I) oleh peneliti. Selanjutnya disusun desain draf 2 Pembelajaran Integratif. Desain draf 2 ini diujicobakan dengan diimplementasikan dalam proses tutorial. Pada saat uji coba dilakukan pengamatan dan dimintakan pendapat/tanggapan mahasiswa serta tutor. Hasil pengamatan di lapangan dan masukan-masukan dari mahasiswa maupun tutor digunakan sebagai bahan pertimbangan dalam melakukan revisi II perangkat rencana tutorial. Masukan dari mereka menjadi dasar untuk mengembangkan produk draf 3 yang merupakan produk akhir dari penelitian ini.

\section{4) Tahap Desiminasi (Desseminate)}

Desiminasi terbatas dalam bentuk seminar nasional hasil penelitian dilaksanakan di UT atau Institusi lain yang relevan.

\section{HASIL DAN PEMBAHASAN Tahap Pendefinisian}

Berdasarkan rancangan penelitian ini, pada tahap pendefinisian dilakukan studi pendahuluan mengenai kurikulum pada program studi S1 PGSD, analisis mahasiswa, analisis kompetensi yang akan dicapai dalam matakuliah Materi dan Pembelajaran IPA SD, analisis konsep (struktur isi matakuliah), dan analisis tugas tutorial, kemudian dilakukan pendefinisian pembelajaran integratif antara matakuliah Materi dan Pembelajaran IPA SD dengan Konsep Dasar IPA.

Hasil studi pendahuluan mengenai kurikulum program studi S1 PGSD UT yang berkaitan dengan mata kuliah Materi dan Pembelajaran IPA dan mata kuliah Konsep Dasar IPA adalah sebagai berikut:

- $\quad$ Matakuliah konsep dasar IPA ditempuh mahasiswa pada semester II sedangkan matakuliah Materi dan Pembelajaran IPA ditempuh pada semester IX.

- $\quad$ Kandungan materi pada matakuliah Konsep Dasar IPA meliputi: ciri-ciri dan keanekaragaman makhluk hidup, makhluk hidup dan lingkungannya, organ tubuh manusia, perkembangan makhluk hidup, struktur tubuh pada manusia, makanan, kesehatan penyakit dan pencegahannya, kinematika dan dinamika, materi dan sifatnya, gelombang dan bunyi, optika, listrik dan magnet, bumi dan alam semesta. Sedangkan topik materi pada matakuliah Materi dan Pembelajaran IPA adalah pendidikan kehidupan keluarga, fluida, adaptasi dan evolusi, penurunan sifat, pengenalan senyawa organik dan biokimia, pengantar bioteknologi, dasardasar elektronika, model-model pembelajaran IPA, pembelajaran IPA dengan pendekatan lingkungan dan masyarakat. 
- Jika dikaitkan dengan materi IPA di sekolah Dasar, maka materi pada mata kuliah Konsep Dasar IPA sangat mendukung materi IPA di SD dibandingkan materi pada matakuliah Materi dan Pembelajaran IPA. Oleh karena itu matakuliah Materi dan Pembelajaran IPA akan lebih baik jika ditekankan pada pembelajaran IPA. Hal ini dikuatkan dengan hasil analisis mahasiswa UT pada semester $X$ yang mengikuti tutorial matakuliah PKP, yaitu mahasiswa kurang mampu untuk membuat rencana perbaikan pembelajaran (RPP) yang akan diterapkan dalam kegiatan PTK (penelitian tindakan kelas), padahal mahasiswa PGSD adalah guru yang sudah pengalaman mengajar.

- $\quad$ Kompetensi yang akan dicapai dalam matakuliah Materi dan Pembelajaran IPA ada dua yaitu kompetensi penguasaan materi IPA dan kompetensi dalam pembelajaran IPA. Kompetensi penguasaan materi IPA didukung oleh matakuliah konsep dasar IPA, sedangkan kompetensi dalam pembelajaran IPA lebih dikembangkan lagi dari bahan tutorial yang tersedia. Tugas tutorial yang diberikan kepada mahasiswa lebih ditekankan pada kompetensi pembelajaran IPA.

- Berdasarkan hasil studi pendahuluan, analisis materi, analisis mahasiswa dan tugas tutorial, maka dapat didefinikan model pembelajaran integratif dalam mata kuliah Materi dan Pembelajaran IPA dengan matakuliah Konsep Dasar IPA yaitu: mengintegralkan konsepkonsep IPA dan model-model pembelajaran dalam membuat RPP (Rencana Pelaksanaan Pembelajaran atau Rencana Perbaikan Pembelajaran). Hal ini dipilih karena letak kelemahan mahasiswa dalam pembuatan RPP. Dengan demikian waktu tutorial untuk kegiatan ini diberikan porsi yang lebih banyak.

\section{Tahap Perancangan}

Pada tahap perancangan ini dilakukan identifikasi terhadap komponen-komponen matakuliah, meliputi kompetensi yang akan dicapai, pokok dan sub pokok bahasan, aktivitas, media, dan sumber belajar untuk mendukung pencapaian kompetensi, serta evaluasi untuk mengukur pencapaian kompetensi. Komponen-komponen tersebut selanjutnya disusun dalam kerangka dan sitematika sesuai dengan format yang berlaku, berupa Rancangan Aktivitas Tutorial (RAT), Satuan Acara Tutorial (SAT), Rancangan Evaluasi (RE), dan Lembar kerja Mahasiswa (LKM).

Rancangan Aktivitas Tutorial (RAT) tetap mengacu pada modul utama, yaitu Materi dan Pembelajaran IPA di SD. Materi Konsep Dasar IPA diimplementasikan pada saat pembuatan RPP yang dituangkan dalam Lembar Kerja Mahasiswa (LKM) dan Rancangan Evaluasi (RE) serta di dalam Satuan Acara Tutorial (SAT). Di dalam pebuatan RPP mahasiswa diberi kebebasan untuk memilih topik materi yang dikuasai yang sesuai dengan Kompetensi Dasar yang diharapkan pada diri siswa.

\section{Tahap Pengembangan}

Pada tahap pengembangan, semua komponen yang telah siap pada tahap perancangan, meliputi RAT, SAT, RE, dan LKM selanjutnya dijadikan dasar untuk mengembangkan draf I panduan pembelajaran integratif dalam matakuliah Materi dan Pembelajaran IPA SD dengan Konsep Dasar IPA. Perangkat rencana tutorial matakuliah Materi dan Pembelajaran IPA SD yang telah disusun, mencakup: RAT, SAT, RE, dan LKM berupa draf 1 pembelajaran Integratif ditelaah oleh pakar pembelajaran IPA dengan lembar validasi seperti pada lampiran 1. Berdasarkan hasil telaah tersebut kemudian perangkat rencana tutorial direvisi (revisi I) oleh peneliti. Selanjutnya disusun desain draf 2 Pembelajaran Integratif. Desain draf 2 ini diujicobakan dengan diimplementasikan dalam proses tutorial. Pada saat uji coba dilakukan pengamatan dan dimintakan pendapat/tanggapan mahasiswa serta tutor. Hasil pengamatan di lapangan dan masukan-masukan dari mahasiswa maupun tutor 
digunakan sebagai bahan pertimbangan dalam melakukan revisi II perangkat rencana tutorial. Masukan dari mereka menjadi dasar untuk mengembangkan produk draf 3 yang merupakan produk akhir dari penelitian ini.

\section{Hasil dan Pembahasan Panduan Pembelajaran Integratif}

Panduan pembelajaran integratif yang dihasilkan berupa, Rancangan Aktivitas Tutorial (RAT), Satuan Acara Tutorial (SAT), Rancangan Evaluasi (RE), dan Lembar Kerja Mahasiswa (LKM). Panduan ini merupakan hasil pengintegrasian mata kuliah materi dan pembelajaran IPA di SD dengan mata kuliah Konsep dasar IPA. Letak penggabungan pada lembar kerja mahasiswa, yaitu pada pembuatan RPP. Dalam pembuatan RPP ini mahasiswa dituntut untuk menguasai dua aspek yaitu aspek pembelajaran (meliputi model, pendekatan, dan metode pembelajaran) dan aspek penguasaan materi IPA.

Pengembangan panduan pembelajaran integratif ini didasarkan pada 4D model yang telah dijelaskan pada metodologi di atas. Setelah melalui tahap validasi dari teman sejawat tutor dan mahasiswa, maka produk akhir panduan ini dinyatakan cukup layak digunakan. Perlu juga dilakukan penyempurnaan lebih lanjut untuk hasil yang lebih baik.

\section{Hasil dan Pembahasan Ujicoba Pembelajaran Integratif}

Karena keterbatasan waktu pelaksanaan ujicoba, maka ujicoba hanya dilakukan selama 3 kali, yaitu pada pertemuan keenam, ketujuh dan kedelapan. Dari tiga kali pertemuan tersebut dihasilkan data aktivitas tutor, mahasiswa, respon mahasiswa, dan nilai tugas tutorial ketiga. Aktivitas tutor secara umum dalam kategori baik dan cukup baik. Demikian juga aktivitas mahasiswa dalam mengikuti kegiatab tutorial dalam kategori baik dan cukup baik.

Respon mahasiswa untuk mengikuti kegiatan tutorial sebagian besar menyatakan cukup senang dan membantu dalam penyusunan RPP di tempat mengajarnya. Tetapi alokasi waktu kegiatan tutorial, sebagian besar mahasiswa menyatakan kurang memadai, perlu ditambah lagi terutama dalam tugas penyusunan RPP. Penilaian mahasiswa yang berkaitan dengan lembar kerja mahasiswa (LKM) sebagian besar menyatakan cukup baik untuk membantu dalam pemahaman konsep-konsep sains dan pembelajarannya.

Nilai tugas tutorial ketiga memiliki rata-rata 75. Hal ini menunjukkan bahwa mahasiswa cukup memahami materi yang ditutorkan. Dari hasil pengamatan dan hasil tugas tutorial memang mahasiswa mengalami kesulitan dalam merancang langkah-langkah pembelajaran yang sesuai dengan model pembelajaran yang digunakan. Dari hasil wawancara dengan beberapa mahasiswa dapat disimpulkan bahwa di sekolah tempat ia mengajar jarang sekali digunakan model-model pembelajaran dalam menyusun RPP dan kebanyakan hanya menggunakan metode saja (misalkan ceramah atau diskusi).

\section{KESIMPULAN DAN SARAN Kesimpulan}

1. Implementasi pembelajaran integratif dalam kegiatan tutorial matakuliah Materi dan Pembelajaran IPA SD dengan Konsep Dasar IPA terdapat pada lembar kerja mahasiswa (LKM) dan telah dihasilkan draf panduan pembelajaran integratif yang cukup layak digunakan.

2. Implementasi pembelajaran integratif dalam kegiatan tutorial matakuliah Materi dan Pembelajaran IPA SD dengan Konsep Dasar IPA dapat meningkatkan penguasaan konsep dasar IPA dan kemampuan membuat perencanaan pembelajaran pada mahasiswa S-1 PGSD pokjar Kabupaten Tuban. 
3. Implementasi pembelajaran integratif dalam kegiatan tutorial matakuliah Materi dan Pembelajaran IPA SD dengan Konsep Dasar IPA cukup memberikan dapak positif terhadap prestasi belajar matakuliah Materi dan Pembelajaran IPA SD pada mahasiswa S-1 PGSD Pokjar Kabupaten Tuban.

\section{Saran}

1. Perlu dilakukan penelitian lebih lanjut untuk menyempurnakan draf panduan pembelajaran integratif ini.

2. Perlu ditambahkan materi tentang model-model pembelajaran dalam mata kuliah di jurusan PGSD, baik matakuliah yang berdiri sendiri, maupun masuk dalam beberapa mata kuliah yang relevan.

\section{REFERENSI}

Ali, M. (1990). Penelitian Kependidikan. Bandung: Angkasa.

Bell, B. (1993). Children's science: Constructivism and learning in science. Geelong, Victoria: Deakin University Press.

Carin A.A. \& Sund. (1980). Teaching science through discovery. Ohio: Columbus Merrill Publishing.

Dahar, R. W. (1985). Kesiapan guru mengajarkan sains di sekolah dasar: Ditinjau dari segi pengembangan keterampilan proses sains (suatu humatif tentang proses belajar mengajar sains di Kelas 4,5 dan 6 sekolah dasar): Desertasi Doktor yang tidak dipublikasikan. FPS IKIP Bandung.

Depdikbud. (1994). Kurikulum pendidikan dasar (landasan, program dan pengembangan). Jakarta: Dirjen Dikti.

Gabel, D. L., (ed). (1993). Hand book of research on science teaching and learning. A project of the national science. Teacher Association. New York: Macmillan Publishing Company.

Harlen, W. \& Russell, T. (1990). Assessing science in the primary classroom. London: Paul Chapman Publ. Ltd. P.116.

Hinduan, A. A.,et al. (2000). The development of teaching and learning science models at primary school and primary school teachereducation'Final Report to The University Research for Graduate Education Project. Directorate General of Higher Education.

Indrawati, (2000). Model-model pembelajaran IPA, Bandung: PPPG IPA.

Kauchak, P.P. \& Eggen, P.D. (1989). Strategies for teacher. Teaching content and thinking skill. Boston: Allyn \& Bacon.

Kresnadi, H. (2001). Pengembangan bentuk tes keterampilan proses sains dalam pembelajaran IPA di kelas III SD. Tesis yang tidak dipublikasikan. PPS. UPI. Bandung.

Mason,J.F. (1989). Reading and writing connection. London:University of Illinois at Urbana.

Rustaman, N. (1995). Pengembangan butir soal keterampilan proses sains, disusun sebagai bahan penyuluhan untuk disampaikan dan dilatihkan kepada guru-guru SD dalam rangka pengabdian pada masyarakat. Makalah. Bandung: FPMIPA IKIP.

Sahertian. (1994). Dimensi-dimensi administrasi pendidikan di sekolah. Malang: Mataram Muda.

Satori, D. (1996). Supervisi akademik (teori dan praktek). Jakarta: Depdikbud.

Semiawan, C. (1992). Pendekatan keterampilan proses bagaimana mengaktifkan siswa dalam belajar. Jakarta : PT. Gramedia.

Sumaji, dkk. (1998). Pendidikan sains yang humanistis. Yogyakarta: Kanisius.

Supriadi, D. (1998). Mengangkat citra dan martabat guru. Bandung: Adicita Karya Nusa. 
Thiagarajan, S., Semmel, D.S. \& Semmel, M.I. (1974). Instructional development for training teachers of exceptional children. Indiana: Indiana University Bloomington.

Wahab,R. dan Solehuddin. (1998). Perkembangan dan belajar peserta didik. Jakarta: Departemen Pendidikan dan Kebudayaan Direktorat Jenderal Pendidikan tinggi.

Yager, R. E., Hidayat, E. H., \& Penick, J. E. (1988). Features which separate least effective from most effective science teachers. Journal of research in science teaching, 25(3), 165-177. 